\title{
Influence of Partial Replacement of Cement and Sand with Coal Bottom Ash on Concrete Properties
}

\author{
Mohammed Yahya Mohammed Al-Fasih, Mohd Haziman Wan Ibrahim, Nurul Fasihah Basirun, \\ Ramadhansyah Putra Jaya, Mohd Syahrul Hisyam Mohd Sani
}

\begin{abstract}
An experimental study was accomplished to study the effect of replacement of both cement and sand with coal bottom ash (CBA) on the properties of the concrete. Control mix was prepared without coal bottom ash replacement and nominated as series $A$. The mixes of series $B$ were prepared with20 \% replacement of cement with 30 hours ground coal bottom ash $(G C B A)$. Mixes of series $C$ were prepared with four percentages $(5,10,15,20)$ of $C B A$ as partial replacement of sand. Mixes of Series $D$ mixes were prepared as a combination of series $B$ and $C$. Slump flow, compressive strength, and water permeability properties were investigated. Series $D$ mixes showed lower workability compared to the series $C$ mixes and control mix. Compressive strength of series $D$ mix gained slightly higher strength compared to the control mix but lower than series $C$ strength. Series $C$ mixes absorbed more water compared to control mix concrete. Series $D$ mixes achieved lower water permeability coefficient compare to series $C$ which showed lower water permeability than the control.
\end{abstract}

Keywords: Coal bottom ash, Partial replacement, Compressive strength, Water permeability

\section{INTRODUCTION}

The higher utilization of concrete leads to an increase in the cement and fine aggregate demand gradually which effects the environment. The utilization of industrial waste products could be an appropriate solution for sustainable development in terms of minimizing environmental pollution and in order to deal with the blooming concern of carbon dioxide (CO2) production [1]. CBA was considered as "green" and environmentally friendly building materials to reduce the constituents of cement in the production of concrete. It is one of the waste materials that has introduced by the Construction

Revised Manuscript Received on October 22, 2019.

* Correspondence Author

Mohammed Yahya Mohammed Al-Fasih, Jamilus Research Center, Faculty of Civil and Environmental Engineering, Universiti Tun Hussein Onn Malaysia, 86400 Parit Raja, Johor, Malaysia. Email: alfaseeh500@gmail.com

Mohd Haziman Wan Ibrahim*, Jamilus Research Center, Faculty of Civil and Environmental Engineering, Universiti Tun Hussein Onn Malaysia, 86400 Parit Raja, Johor, Malaysia. Email: haziman@uthm.edu.my

Nurul Fasihah Basirun, Jamilus Research Center, Faculty of Civil and Environmental Engineering, Universiti Tun Hussein Onn Malaysia, 86400 Parit Raja, Johor, Malaysia. Email: fasihahbasirun92@gmail.com

Ramadhansyah Putra Jaya, Faculty of Civil Engineering Technology, Universiti Malaysia Pahang, 26300 Gambang, Pahang, Malaysia. Email: ramadhansyah@ump.edu.my

Mohd Syahrul Hisyam Mohd Sani, Faculty of Civil Engineering, Universiti Teknologi Mara, Pahang Branch, Bandar Jengka 26400, Pahang, Malaysia. Email: msyahrul210@uitm.edu.my

Industry Development Board (CIDB) for the utilization of recycling material in producing concrete [2]. CBA is produced due to the burning of coal in a thermal power plant and it is considered as major waste with the fly ash (FA). It has a pozzolanic activity which is attributed to the presence of silica oxide ( $\mathrm{SiO} 2)$ and Alumina oxide (A12O3). During cement hydration, calcium hydroxide reacts with CBA results in additional Calcium Aluminate Hydrate (CAH) and Calcium Silicate Hydrate (CSH). Cheriaf et al. [3] stated that an adequate grinding could improve the pozzolanic activity of the CBA, in which grinding of CBA for 6 hours increased the strength activity index of bottom ash at 28 days up to $27 \%$. Therefore, it is being partially replaced fine aggregate and cement in concrete. Bajare et al. [4] concluded that the ground coal combustion bottom ash (CCBA) can replace the cement effectively up to $20 \%$ without decreasing the compressive strength of the concrete. Furthermore, the extension of the CBA grinding period changes the particle size distribution and increases the amounts of fine particles and the density of the concrete. The experimental results by Dembovska et al. [5] displayed that the particle size of CBA becomes smaller than cement with various grinding periods which affect the CBA pozzolanic activity. Thus, the pozzolans in concrete can have dual effects that enhance the physical particle packing and the chemical reaction with calcium hydroxide forming calcium silicate hydrates (CSH). Venkatanarayanan \& Rangaraju [6] investigated the effectiveness of ground CBA as a cement replacement through setting time, microstructure, strength and durability of concrete. The results displayed that the use of ground CBA as a cement replacement can improve the performance of concrete. Kim [7] used sieved and ground coal bottom ash powders as a coarse binder in high-strength mortar. The results revealed that the workability of the mortar mixtures and high-strength paste with ground bottom ash were greater than mixtures with cement with fly ash and cement only. Pyo and Kim's [8] found that silica powder in Ultra High-Performance Concrete was effectively replaced by coal bottom ash and fly ash without significant losses in workability and strength. However, Singh and Siddique [9] found that the utilized coal bottom ash as fine aggregate decreased the workability and bleeding of concrete. Burhanudin et al. [10] obtained that the optimum replacement content of GCBA with cement is $20 \%$ at the grinding time of 
30 hours, resulting in high compressive strength and adequate workability [3].

As mention earlier, the CBA considered as waste material produced by power plants in Malaysia by around 1.7 million tons annually [11]. Thus, by considering the inherent properties of CBA which could decrease solid waste and reduce $\mathrm{CO} 2$ emissions, the use of $\mathrm{CBA}$ in the concrete required further attention and investigation. Limited research studies have been carried out on the using of CBA as a replacement of both cement and sand in concrete simultaneously. Base on Burhanudin et al. [10], replacing the cement with $10 \%$ GCBA gives compressive strength more than the control for all grinding time. Then the strength decreased to be less than the control for replacing $20 \%$ and $30 \%$ GCBA with cement except for the case of replacing $20 \%$ GCBA with cement for 30-hour grinding time which gained higher strength than control. Accordingly, the optimum GCBA replacement content with cement and grinding time was considered as $20 \%$ GCBA of 30 -hour grinding time. It is due to the high strength concrete grade value obtained besides minimal grinding time requirements. The objective of this research paper is to upgrade the work of Burhanudin et al. [10] in which the CBA was used to partially replace sand for the mix of concrete that containing the optimum percentage of GCBA replacement with cement. The findings were compared with those of conventional concrete. The materials were carefully chosen based on their properties such as chemical composition, partial size distribution, specific gravity and fineness modulus.

\section{EXPERIMENTAL}

\section{A. Material}

Ordinary Portland cement (OPC) supplied by Task cement (Malaysia) Sdn. Bhd was used, complying with ASTM C150 [12]. The coarse aggregate used was $10 \mathrm{~mm}$ crushed ballast and fine aggregate with size between $0.15-5 \mathrm{~mm}$ and the specific gravity of 2.61. The coal bottom ash (CBA) was obtained from Sultan Salahuddin Abdul Aziz Power Plant, Kapar, Selangor Darul Ehsan, Malaysia. The CBA and both fine and coarse aggregate were dried in an electronic furnace at a specified temperature of $110^{\circ} \mathrm{C}$ at a heating rate of 20 $\mathrm{C}^{\circ} / \mathrm{min}$ for 24 hours and allowed to call to $20 \mathrm{C}^{\circ}$. The dry CBA was ground for 1 hour in LA Abrasion machine. After the grinding process, CBA was sieved into sieve passing 5 $\mathrm{mm}$ and $600 \mu \mathrm{m}$. Passing $5 \mathrm{~mm}$ in size was used as fine aggregate replacement in concrete. Table 1 shows the comparison between the fineness of the cement and the GCBA-30H obtained from the Fritch Analysette 22 machine. The table indicated that the grinding increased the fineness of the GCBA in which the fineness of GCBA-30H was higher compared to the finance of the cement which is $3310 \mathrm{~cm} 2 / \mathrm{g}$.

Table 1: Physical properties of cement and GCBA

\begin{tabular}{lcc}
\hline Sample & Specific gravity & Fineness $\mathrm{m}^{2} / \mathrm{kg}$ \\
\hline Cement & 3.17 & 331 \\
GCBA-30H & 1.81 & 1192.1 \\
\hline
\end{tabular}

Fig. 1 shows the grading curve of CBA and fine aggregate in the range of grading limits between $150 \mu \mathrm{m}$ to $5 \mathrm{~mm}$, which indicates that the particles size of CBA is acceptable to use as a fine aggregate replacement in this study. The passing 600 $\mu \mathrm{m}$ CBA was ground using the ball mill machine for grinding times 30 hours GCBA-30H, as it is the optimum gringing time according to Burhanudin et al. [10]. The chemical compositions of the cement and GCBA were determined by $\mathrm{X}$-ray fluorescence (XRF) and presented in Table 2. The GCBA contains a high percentage of silica content than cement, which is included in class $\mathrm{F}$ ash and it contains a lower amount of $\mathrm{CaO}$ than cement. Therefore, GCBA has good potential to be used as pozzolanic material for concrete construction.

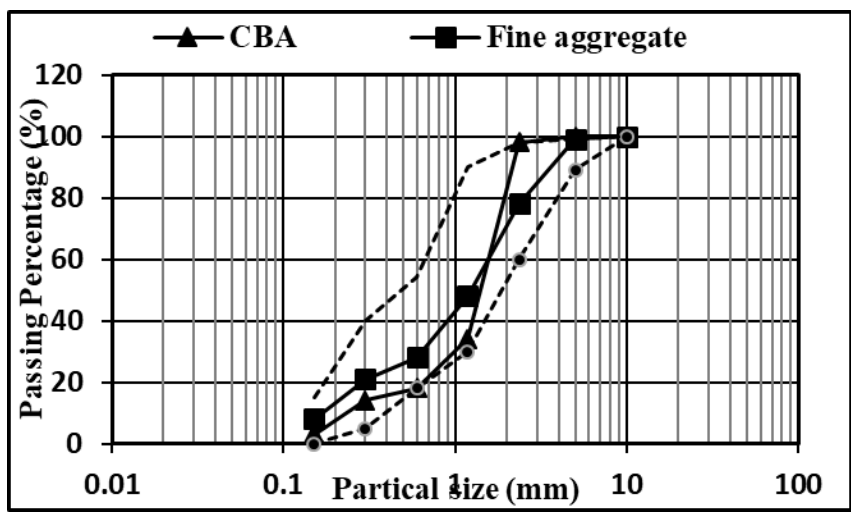

Fig. 1: Grading curve of $\mathrm{CBA}$ and fine aggregate

Table 2: Chemical composition of properties of GCBA

\begin{tabular}{lcc}
\hline \multirow{2}{*}{ Constituents } & \multicolumn{2}{c}{ Percent by weight } \\
\cline { 2 - 3 } & Cement & GCBA-30H \\
\hline Silicon oxide $\left(\mathrm{SiO}_{2}\right)$ & 17.91 & 53.8 \\
Aluminum oxide $\left(\mathrm{Al}_{2} \mathrm{O}_{3}\right)$ & 4.69 & 15.1 \\
Iron oxide $\left(\mathrm{Fe}_{2} \mathrm{O}_{3}\right)$ & 2.97 & 5.27 \\
Calcium oxide $(\mathrm{CaO})$ & 57.1 & 1.32 \\
Potassium oxide $\left(\mathrm{K}_{2} \mathrm{O}\right)$ & 0.51 & 1.00 \\
Titanium dioxide $(\mathrm{TiO})$ & - & 0.91 \\
$\mathrm{Magnesium} \mathrm{oxide}(\mathrm{MgO})$ & 1.62 & 0.53 \\
Sodium oxide $\left(\mathrm{Na}_{2} \mathrm{O}\right)$ & - & 0.23 \\
$\mathrm{Carbon}(\mathrm{C})$ & 3.43 & 0.10 \\
SiO $_{2}+\mathrm{Al}_{2} \mathrm{O}_{3}+\mathrm{Fe}_{2} \mathrm{O}_{3}$ & 25.56 & 78.26 \\
\hline
\end{tabular}

\section{B. Mix proportion}

The experimental work was designed into four series which are, series A, B and C and D. Series A was designed as a control model base on Design of Experimental (DOE) method for concrete grade 30. Series B was designed in which the cement partially replaced with optimum content and time grinding of GCBA. In this Series, the contents of water and both fine aggregate were fixed and the cement was replaced with $20 \%$ GCBA by weight for grinding time of 30 
hours.

Table 3: Mix proportion

\begin{tabular}{|c|c|c|c|c|c|c|c|}
\hline \multirow{2}{*}{ Series } & \multirow{2}{*}{ Designation } & \multicolumn{2}{|c|}{$\mathrm{CBA}\left(\mathrm{kg} / \mathrm{m}^{3}\right)$} & \multirow{2}{*}{$\begin{array}{l}\text { Cements } \\
\left(\mathrm{kg} / \mathrm{m}^{3}\right)\end{array}$} & \multirow{2}{*}{$\begin{array}{c}\text { Water } \\
\left(\mathrm{kg} / \mathrm{m}^{3}\right)\end{array}$} & \multicolumn{2}{|c|}{ Aggregate $\left(\mathrm{kg} / \mathrm{m}^{3}\right)$} \\
\hline & & GCBA & $\mathrm{CBA}$ & & & Fine & Coarse \\
\hline A & control & 0 & 0 & 460 & 230 & 958 & 722.4 \\
\hline B & M20CR & 92 & 0 & 368 & 230 & 958 & 722.4 \\
\hline \multirow{4}{*}{$\mathrm{C}$} & M5SR & 0 & 47.9 & 460 & 230 & 910.1 & 722.4 \\
\hline & M10SR & 0 & 95.8 & 460 & 230 & 862.2 & 722.4 \\
\hline & M15SR & 0 & 143.7 & 460 & 230 & 814.3 & 722.4 \\
\hline & M20SR & 0 & 191.6 & 460 & 230 & 766.4 & 722.4 \\
\hline \multirow{4}{*}{$\mathrm{D}$} & M5SR20CR & 92 & 47.9 & 368 & 230 & 910.1 & 722.4 \\
\hline & M10SR20CR & 92 & 95.8 & 368 & 230 & 862.2 & 722.4 \\
\hline & M15SR20CR & 92 & 143.7 & 368 & 230 & 814.3 & 722.4 \\
\hline & M20SR20CR & 92 & 191.6 & 368 & 230 & 766.4 & 722.4 \\
\hline
\end{tabular}

Series $\mathrm{C}$ was designed at fixed cement, coarse aggregate and water content, and the sand were partially replaced with 5\%, $10 \%, 15 \%$, and $20 \%$ of CBA by weight. Series D was designed same as series $\mathrm{C}$ with taking into account that the content of cement will be partially replaced with the optimum content of the GCBA as "series B". This resulted in 10 different mixtures as listed in Table 3.

\section{Preparation and casting of test specimens}

The materials of each mixture series were mixed in a dry state using the mixer to obtain homogenous mix. After the water added, the mixing operation was performed until obtain the proper mixing. Then the fresh mix properties i. e. slump tests were immediately conducted. Then, the specimens were cast into the specific mold for different hardened properties testing. After 24 hours, the specimens were removed from the molds and cured in water until testing. Three cubical specimens for each mixture were prepared with a size of 100 $\mathrm{mm}$ to determine the compressive strength and $150 \mathrm{~mm}$ for water permeability at age of 7, 28, 56, 90 and 180 days.

\section{Testing of the specimens}

\section{1) Properties of fresh concrete}

The workability test was performed according to BS EN 12350-2 [13] to evaluate fresh mix concrete properties. The tool involves a cone mold with a top diameter of $10 \mathrm{~cm}$, a base diameter of $20 \mathrm{~cm}$, and a height of $30 \mathrm{~cm}$.

\section{2) Hardened properties}

- Compressive strength

Compressive strength tests were determined by crushing three $100 \mathrm{~mm}$ cubes for each case at age of 7 , 28, 56, 90 and 180 days as per BS EN 12390-3:2009 [14]. The average of the three values at each age were determined.

\section{- Water permeability}

Water permeability of the cured specimens was evaluated at the age of 7, 28, 56, 90 and 180 days by measuring the water penetration depth under pressure using concrete permeability apparatus as per BS EN $12390-8$ [15]. The water pressure of $500 \pm 50 \mathrm{KPa}$ was applied for $72 \pm 2$ hours. The equation of Valenta's (Valenta, 1970) was used to calculate the water permeability coefficient, $K p,(\mathrm{~m} / \mathrm{s})$.

$K p=\left(\mathrm{d}^{2} v\right) / 2 h t$

where $d$ is the water penetration depth in concrete (m), $v$ is the concrete porosity, $h$ is the hydraulic water head (m), and $\mathrm{t}$ is the time of sample under pressure (s).

The concrete porosity was determined based on the following equation:

$v=m / A d p$

where $\mathrm{m}$ is the increase in mass $(\mathrm{g}), \mathrm{A}$ is the specimen's cross-sectional area $(\mathrm{mm} 2)$ and $\mathrm{p}$ is the water's density $(1000 \mathrm{~kg} / \mathrm{m} 3)$.

\section{RESULTS AND DISCUSSION}

\section{A. Fresh concrete properties}

The workability of fresh concrete samples was evaluated in terms of the slump test. The comparison of the slump test values for series A (control), series B (M20CR), series C and series D was shown in Fig. 4. In the figure, the concrete with $5 \%$ CBA replacement with sand gained higher slump value compared to the control concrete. Then the slump value decreases linearly with the increase of CBA percentage in which the concrete with $10 \%, 15 \%$, and $20 \%$ gained lower slump values than the control concrete. The decrease in the slump value proves that CBA particles have higher water absorption rate compared to the fine aggregate particles where the water in the cement paste was likely to be absorbed into pore on the surface of particles, hence resulting in lower workability. Also, the reduction of free water for the lubrication of particles is due to the internal absorption of the water by the dry and porous particles. These findings are in line with the studies carried out 
by Wan Ibrahim et al. [16], Zainal Abidin et al. [17] and

Mangi et al. [1].

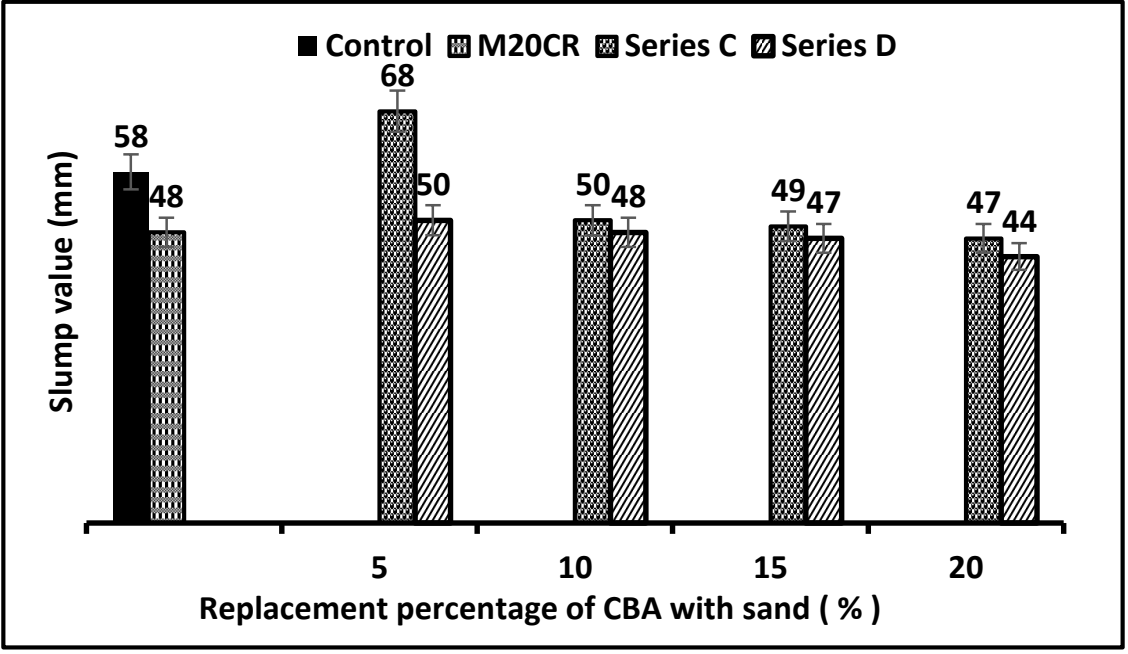

Fig. 4: Comparison of the workability of series $C$ and series D with respect to control and M20CR

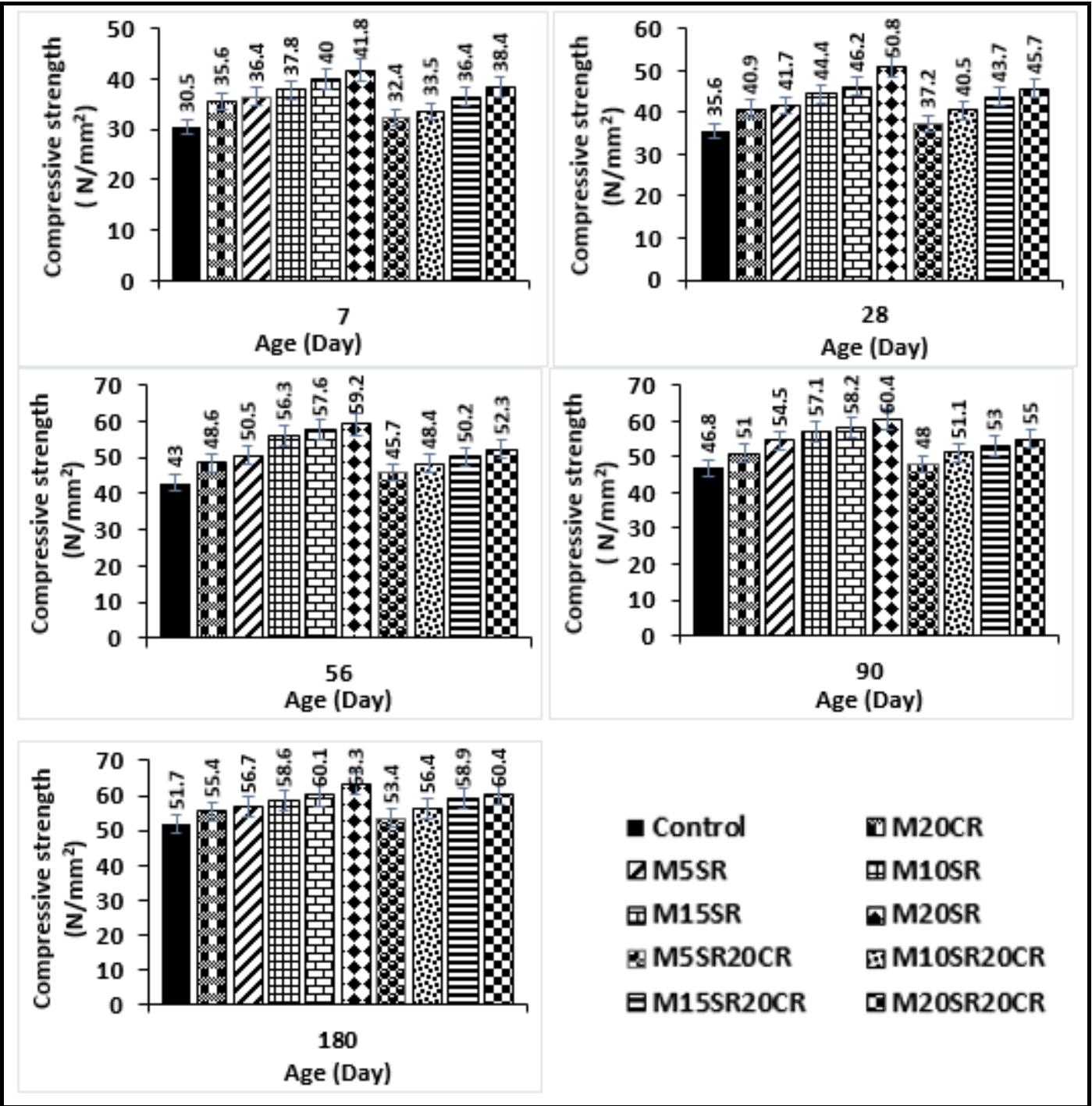

Fig. 5 compressive strength of the concrete containing GCBA and CBA

On the other hand, for the samples of series $\mathrm{D}$, at $5 \%$ $\mathrm{CBA} /$ sand the slump value was higher than that of M20CR specimen but lower than that of the control. Then, the slump value decreased linearly with the increase of CBA percentage as well. This reduction because of the GCBA possesses a

large number of porous particles, which absorbs more water. The larger surface area and high porosity of CBA attributed to absorbing more water. As reported by Zainal

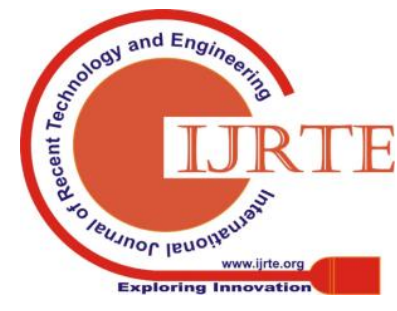


Abidin et al. [17], the slump value decrease is due to CBA porosity, which absorbed more water with a higher replacement content with cement.

Thus, workability is decreasing with replacing $20 \%$ GCBA with cement.

Generally, it was observed that the concrete workability increased due to $5 \%$ sand replacement with $\mathrm{CBA}$ for both series $\mathrm{C}$ and $\mathrm{D}$ and then decreased when replaced $10 \%, 15 \%$ and $20 \%$. Furthermore, series D mixes gained lower slump values than those of series $\mathrm{C}$ for all percentages of CBA. In another word, fresh concrete containing $\mathrm{CBA} /$ sand and GCBA/cement attained lower in slump value compared to fresh concrete of the control, and concrete containing $\mathrm{CBA} /$ sand only.

\section{B. Hardened concrete properties}

\section{- Compressive strength}

The compressive strength results of series A (control), series B (M20CR), series C and series D are presented in Fig. 5. The test results indicated that the compressive strength of M20CR specimens was higher than the control mix at all curing ages. The increase of the compressive strength is due to the high silica content and fine particle size of GCBA which led to the excellent pozzolanic activity.

The compressive strength of Series $\mathrm{C}$ mixture gained a higher compressive strength than the control specimens. Besides, their compressive strength increased gradually with respect to the increase of the CBA percentage for all ages.

The compressive strength of Series D mixture gained slightly higher strength compared to that of control mix concrete. For instance, at the age of 28 days, the compressive strength $4.5 \%, 13.7 \%, 22.7 \%$ and $28.4 \%$ higher than control specimen for M5SR20CR, M10SR20CR, M15SR20CR and M20SR20CR, respectively. However, the specimens of series D gained compressive strength lower than those of series C. Also, the compressive strength of this series increased with the increase of CBA percentage. The drop in strength is due to the increasing replacement amount of bottom ash that producing porous concrete with more pores spread around the bottom ash aggregate surface [17]. Ghafoori and Bucholc [18] had reported that strength reduction is due to the high water absorption rate of the angular shape and very porous surface of the bottom ash resulting in a decrease of the strength as the amount of replacement CBA increase.

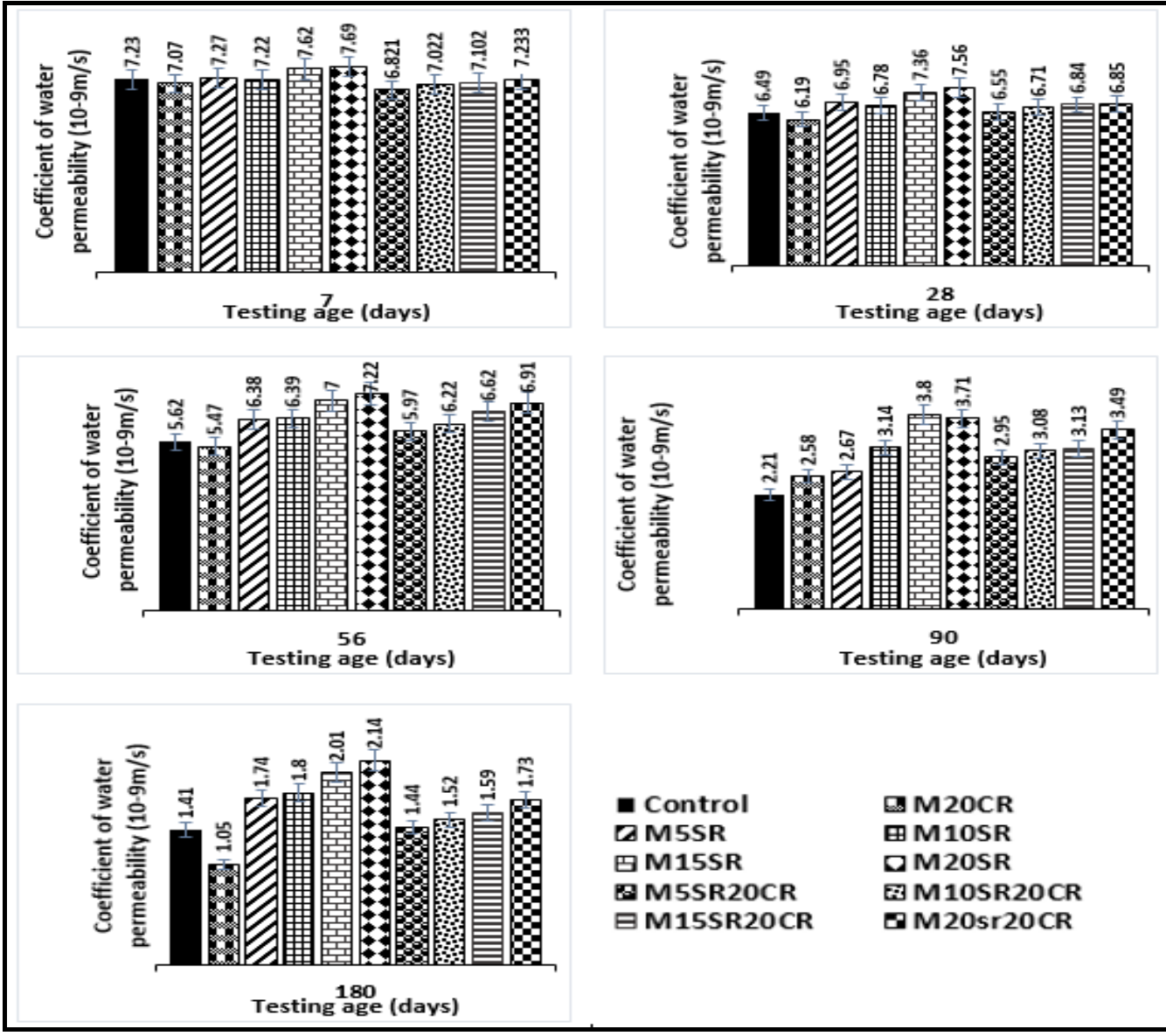

Fig. 6: Water Permeability Coefficient of GCBA concrete with respect to age of curing

\section{- Water permeability}

Permeability of the concrete is one of the main parameters that could represent the durability performance of the concrete [19]. Fig. 6 shows coefficient of the water permeability results at the age of 7,28 , 56, 90 and 180 days. In the figure, lower water

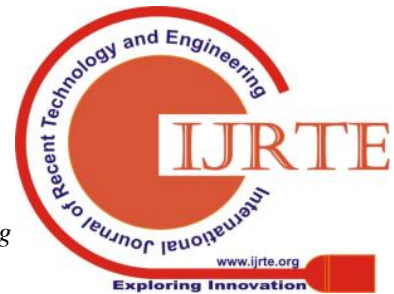


permeability coefficient characteristics indicated the higher durability of concrete.

The water permeability coefficient was increased with the increase of CBA percentage replacement with sand. It means that the sand replacement with CBA was reduced the concrete resistance for water permeation. The effect of CBA on the water permeability of concrete specimens was similarly observed by research of Marto et al. [20]. Hashemi et al. [21] stated that The increasing demand for water is due to the porous nature of CBA resulting in an increase in concrete pores. Thus, CBA absorbed more water in concrete compared to that of control mix. Hence, this phenomenon characterizes the CBA to possess more permeable properties as compared to control mix concrete.

On the other hand, the combination of GCBA/cement and $\mathrm{CBA} /$ sand could further enhance the durability of concrete. Based on Fig. 6, 20\% GCBA in combination with each of $5 \%, 10 \%, 15 \%$ and $20 \%$ CBA achieved lower water permeability coefficient as compared to specimens containing $\mathrm{CBA} /$ sand only, and as well the control mix concrete. This is due to the increased specific surface when adding GCBA content, which generates more water flow through voids between the particles.

\section{CONCLUSION}

a) Replaced $5 \%$ of $\mathrm{CBA} /$ sand increased workability about $17 \%$ compared to the control mix but decreased about $16 \%, 18 \%$ and $23 \%$ due to replaced $10 \%, 15 \%$ and $20 \%$ CBA/sand.

b) Concrete containing $\mathrm{CBA} /$ sand and the optimum amount of GCBA/cement showed lower workability compared to the concrete containing $\mathrm{CBA} /$ sand.

c) It was found that $\mathrm{CBA} /$ sand replacement decrease compressive strength at age 7 days but later found to be more than the control mix, besides the strength increased linearly as the $\mathrm{CBA} /$ sand replacement increase.

d) Compressive strength of series D mix was slightly higher than the strength of control mix concrete but significantly lower than series $\mathrm{C}$ strength, and it is slightly effected by the increase of CBA/sand.

e) Concrete containing $\mathrm{CBA} /$ sand absorbed more water than control mix concrete. The coefficient of water permeability increase as the $\mathrm{CBA} /$ sand increase.

f) Concrete containing the optimum dosage of GCBA/cement and CBA/sand achieved lower water permeability coefficient compare to that containing $\mathrm{CBA} /$ sand and the control mix concrete as well.

\section{REFERENCES}

1. S.A. Mangi, M.H.W. Ibrahim, N. Jamaluddin, S. Shahidan, M.F Arshad, S.A. Memon, R.P. Jaya, S.W. Mudjanarko, M.I. Setiawan, Influence of ground coal bottom ash on the properties of concrete, International Journal of Sustainable Construction Engineering and Technology. 9 (2018) 26-34.

2. R. Dwikojuliardi, (2015). Malaysia and construction industry, Malaysia construction research journal. 2(1). 22-45.

3. M. Cheriaf, J.C. Rocha, J. Pera, Pozzolanic properties of pulverized coal combustion bottom ash, Cement and Concrete Research. 29 (1999) 1387-1391.

4. D. Bajare, G. Bumanis, L. Upeniece, Coal combustion bottom ash as microfiller with pozzolanic properties for traditional concrete, Procedia Engineering. 57 (2013) 149-158.
5. L. Dembovska, D. Bajare, I. Pundiene, L. Vitola, Effect of pozzolanic additives on the strength development of high performance concrete, Procedia Engineering. 172 (2017) 202-210.

6. H.K. Venkatanarayanan, P.R. Rangaraju, Effect of grinding of low-carbon rice husk ash on the microstructure and performance properties of blended cement concrete, Cement and Concrete Composites. 55 (2015) 348-363.

7. H.-K. Kim, Utilization of sieved and ground coal bottom ash powders as a coarse binder in high-strength mortar to improve workability, Construction and Building Materials. 91 (2015) 57-64.

8. S. Pyo, H.-K. Kim, Fresh and hardened properties of ultra-high performance concrete incorporating coal bottom ash and slag powder, Construction and Building Materials. 131 (2017) 459-466.

9. M. Singh, R. Siddique, Effect of coal bottom ash as partial replacement of sand on workability and strength properties of concrete, Journal of Cleaner Production. 112 (2016) 620-630.

10. M. K. Burhanudin, M. H. W. Ibrahim, M. S. H. M. Sani, M. I. Juki, N. Jamaluddin, R. P. Jaya, M. Z. M. Bosro, Influence of ground coal bottom ash with different grinding time as cement replacement material on the strength of concrete. Malaysian Construction Research Journal, 4(2 Special Issue) (2018) 93-102.

11. M. Rafieizonooz, J. Mirza, M.R. Salim, M.W. Hussin, E. Khankhaje, Investigation of coal bottom ash and fly ash in concrete as replacement for sand and cement, Construction and Building Materials. 116 (2016) 15-24.

12. ASTM International. Standard Specification For Portland Cement West conshohocken,PA, ASTM C150, (2016).

13. BS EN 12350-2, Testing fresh concrete, Slump test. (2000).

14. BS EN 12390-3: 2009: Testing hardened concrete. Compressive strength of test specimens. BSI. (2009).

15. BS EN 12390-8: 2009: Testing hardened concrete-Part 8: Depth of penetration of water under pressure. BSI. (2009).

16. M.H.W. Ibrahim, A.F. Hamzah, N. Jamaluddin, P.J. Ramadhansyah, A.M. Fadzil, Split tensile strength on self-compacting concrete containing coal bottom ash, Procedia-Social and Behavioral Sciences 195 (2015) 2280-2289.

17. Z. Abidin, N. Ernida, W. Ibrahim, M. Haziman, N. Jamaluddin, K. Kamaruddin, A.F. Hamzah, The effect of bottom ash on fresh characteristic, compressive strength and water absorption of self-compacting concrete, in: Applied Mechanics and Materials, Trans Tech Publ, 2014: pp. 145-151.

18. N. Ghafoori, J. Bucholc, Investigation of lignite-based bottom ash for structural concrete, Journal of Materials in Civil Engineering. 8 (1996) 128-137.

19. P.J. Ramadhansyah, A.W. Mahyun, M.Z.M. Salwa, B.H.A. Bakar M.A.M. Johari, M.H.W. Ibrahim, Thermal analysis and pozzolanic index of rice husk ash at different grinding time, Procedia Engineering. (2012) 101-109.

20. A. Marto, A.R. Awang, A.M. Makhtar, Compaction Characteristics and Permeability Of Tanjung Bin Coal Ash Mixtures, in: IPCBEE in Proc. of the International Conference on Environment Science and Engineering: Selected Papers. Ed. By IACSIT Press, Singapore, 2011: pp. 134-137.

21. S.S.G. Hashemi, H. Bin Mahmud, J.N.Y. Djobo, C.G. Tan, B.C. Ang, N. Ranjbar, Microstructural characterization and mechanical properties of bottom ash mortar, Journal of Cleaner Production. 170 (2018) 797-804.

\section{AUTHORS PROFILE}

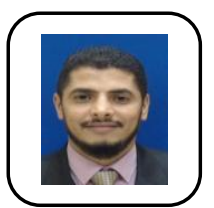

First Author:

$\mathrm{Ph} . \mathrm{D}$ in Civil Engineering and Master in Structura Civil Engineering, Universiti Teknologi Malaysia, Malaysia (UTM). Bachelor degree in Civil Engineering, University of Mosul, Iraq. Post-doctoral fellow at the faculty of civil and environmental engineering, University Tun Hussein Onn Malaysia (UTHM) Published four articles in the top international journals amount to more than 10 total impact factor and one index article.

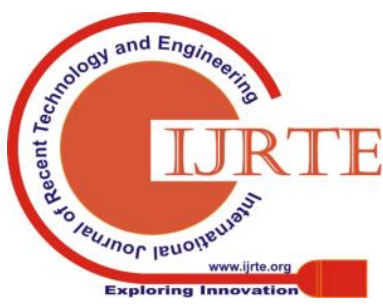


(Academic and International) at Universiti Tun Hussein

Onn Malaysia. He received his BEng, MEng, and PhD in

civil engineering from Universiti Teknologi Mara, Kolej

Universiti Teknologi Tun Hussein Onn Malaysia, and

Universiti Sains Malaysia, Penang, Malaysia, in 1999

2004, and 2011, respectively. His research interests include recycled waste material in construction materials, brick work, and concrete technology.

Third Author Master in Structural Civil Engineering, University Tun Hussein Onn Malaysia (UTHM) (2019) and Bachelor degree in Civil Engineering, University Tun Hussein Onn Malaysia (UTHM) (2015).

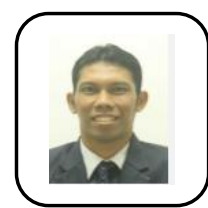

Fourth Author B.Eng in Civil Engineering from Universitas Syiah Kuala, and Master and Doctoral study from Universiti Sains Malaysia. Currently, he is an associate professor in Universiti Malaysia Pahang Malaysia.

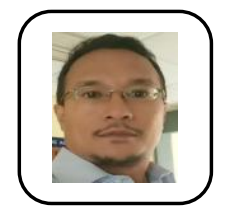

\section{Fifth Author}

He is a Senior Lecturer at Universiti Teknologi MARA $\mathrm{He}$ received his BEng, MEng, and $\mathrm{PhD}$ in civil engineering from Universiti Teknologi MARA, Universiti Putra Malaysia, and Universiti Teknologi Malaysia, in 1999, 2006, and 2019, respectively. His research interests include concrete technology and steel composite structure. 